\title{
The genetic control of self-compatibility in an inbred line of Lolium perenne $\mathrm{L}$
}

\author{
D. THOROGOOD \& M. D. HAYWARD \\ A.F.R.C. Institute of Grassland and Environmental Research, Welsh Plant Breeding Station, Plas Gogerddan, \\ Aberystwyth, Dyfed SY23 3EB, UK
}

\begin{abstract}
The segregating generations derived from a cross of a self-compatible with an incompatible inbred line of Lolium perenne were analysed for the incompatibility reaction as revealed by the pollen/ stigma fluorescence test. All $\mathrm{F}_{1}$ plants showed a half-compatible reaction whilst segregation occurred in the $\mathrm{F}_{2}$ into half- and fully-self-compatible classes. The latter plants bred true in the $\mathrm{F}_{3}$ whilst the former once again showed the same pattern of segregation. These results indicate that the control of self-compatibility is by a single gene $(S c)$ which is gametophytic in action. Further analysis of an intra- $F_{2}$ pollination diallel and of reciprocal cross-pollinations between $F_{2}$ and $F_{1}$ plants reveal that this gene is additional to the $\mathrm{SZ}$ incompatibility system.
\end{abstract}

Keywords: gametophytic, incompatibility, Lolium perenne, pollen, self-compatibility.

\section{Introduction}

Self-incompatibility in Lolium perenne is known to be controlled by a two-locus $(S, Z)$ multiallelic gametophytic system (Cornish et al., 1979) in common with most grasses studied (Hayman, 1956; Lundqvist, 1956, 1961, 1962a, 1965; Murray, 1974; Fearon et al., 1983). This self-incompatibility mechanism, although usually very efficient, occasionally breaks down so that a small number of self seed can be obtained. Early extensive studies by Jenkin (1931) led him to conclude that self-fertility was genotype-dependent and that it should be possible to produce a fully self-fertile plant. Subsequently, many workers have undertaken inbreeding studies on Lolium perenne (Wexelsen, 1952; Beddows et al., 1962; Bean \& Yok-Hwa, 1972). In most cases inbreeding was associated with a reduction in seed set, although Utz \& Oettler (1976) observed an increase in seed production over six generations of selfing. From studies on the early generations of inbreeding, Jones \& Jenabzadeh (1981) suggested that some self-fertile lines had achieved fertility either by selection for polygenic modifiers or by mutation in one of the incompatibility loci.

Mutations of the $S$ locus are well known to give rise to self-fertility in a number of species such as Petunia (Mather, 1943), Nicotiana sp. (East, 1932) and Trifolium (Atwood, 1942; Townsend, 1965) which all possess single-locus gametophytic incompatibility systems (see review of de Nettancourt, 1977). Alternatively, self-fertility may arise by mutation at a locus independent of the $S$ locus as in Trifolium hybridum (Townsend, 1966) or be conditioned by polygenic background modifiers such as those found in interspecific hybrids of Petunia (Mather, 1943) and Lycopersicon (Martin, 1968). Relatively little is known about the genetic control of self-fertility in the Gramineae. In inbred rye, Lundqvist (1960, 1968) showed that self-fertility arose by changes in one of the incompatibility loci, however some of the results he obtained were suggestive of "the existence of an additional kind of major gene, independently inherited and able to turn into an sf determinant'. The present investigation seeks to elucidate the genetic basis of selffertility in an inbred line of Lolium perenne.

\section{Materials and methods}

The basic parental plant material was a pair of inbred lines selected from a number which had previously been screened for their pollen/stigma reaction (Thorogood, 1991). Parent Ba 10354, a ninth-generation inbred derived from the German cultivar Odenwalder, was selected as showing full self-compatibility, whilst parent $\mathrm{Ba} 10355$, a sixth-generation inbred from the WPBS cultivar S23, was completely self-incompatible. Following the crossing of these two parents the $24 F_{1}$ plants obtained were selfed to produce $F_{2}$ and $F_{3}$ families. Within each generation, plants were tested for self-compatibility using the in-vitro method of Lundqvist (1961) and the aniline blue fluorescence technique of Lalouette (1967). Ten $F_{1}$ and $128 F_{2}$ plants 
were assessed for their self- and cross-compatibility. Within the $F_{2}$, a partial diallel of pollinations was carried out amongst 39 plants. Self-compatibility was examined in $19 F_{3}$ families derived from single $F_{2}$ plants chosen at random, each family consisting of from six to thirty individuals.

\section{Results and discussion}

The results of the self-pollinations are summarized in Fig. 1. All $F_{1}$ plants showed a half-compatible reaction when selfed. Intermating of 10 of these plants revealed complete uniformity for pollen tube growth, all crosses displaying the same half-compatible reaction as the selfs. In the $F_{2}$ generation segregation was observed; 73 individuals showing a fully compatible and 65 a half compatible reaction when selfed. There was no evidence of heterogeneity amongst the 16 groups to which the $F_{2}$ plants could be assigned according to which $F_{1}$ plant they derived from. The fully selfcompatible $F_{2}$ plants, when selfed, gave rise to $F_{3}$ progeny all of which were themselves fully self-compatible. In contrast, there was segregation amongst the $F_{3}$ progeny of the half self-compatible $F_{2}$ into either half or fully self-compatible classes.

The observed pattern of compatibilities allows us to draw some conclusions concerning the mode of action and genetic control of self-compatibility in this pair of inbred lines. The presence of both compatible and incompatible pollen in the selfings of the $F_{1}$ indicate gametophytic control in the pollen, although the possibility that the action may be controlled by a combined sporophytic/gametophytic system, as was shown for a case of self-fertility in Trifolium hybridum (Townsend, 1966), cannot be ascertained from the present experimental material. The segregation in the $F_{2}$ into half and fully self-compatible classes agrees closely with the $1: 1$ ratio expected if the control is by a single gene $\left(\chi^{2}=0.46, P=0.50\right)$ and it is assumed that only pollen carrying the self-compatibility gene can effect fertilization whilst on the female side both the compatibility and incompatibility factors are transmitted. The absence of self-incompatible plants in the $F_{2}$ would confirm that this assumption is correct. The pattern in the $\mathrm{F}_{3}$ confirms this hypothesis in that fully self-compatible $F_{2}$ only give rise to fully self-compatible progeny and segregation occurs among the progeny of the half self-compatible parents. Amongst these latter families, however, there was a slight but significant excess of half compatible plants $(76: 52$, $\left.\chi^{2}=4.5, P=0.05-0.03\right)$. Such deviation from expectation may be accounted for by selection in favour of the heterozygous state which has been shown to occur during the early generations of inbreeding in related lines of the present material (Albini, 1982).

The identification of a single gene controlling selfcompatibility in the parental line $\mathrm{Ba} 10354$ raises the

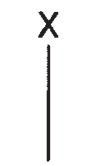

$F_{1}$

$F_{3}$

Number of plants
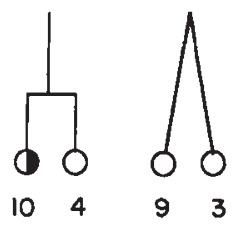
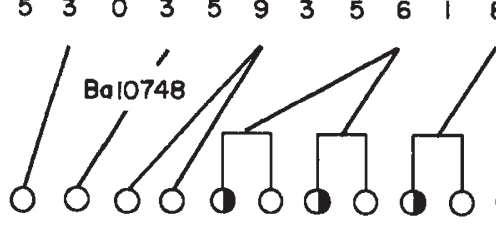

\begin{tabular}{llllllllll}
\hline & 5 & 6 & 6 & 6 & 3 & 6 & 2 & 1
\end{tabular}

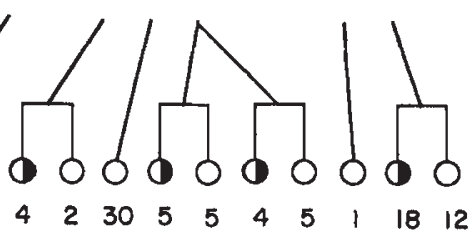

Fig. 1 Segregation of self-compatibility in Cross 1 . (०) Fully compatible, (๑) half compatible, $(\bullet)$ incompatible. 


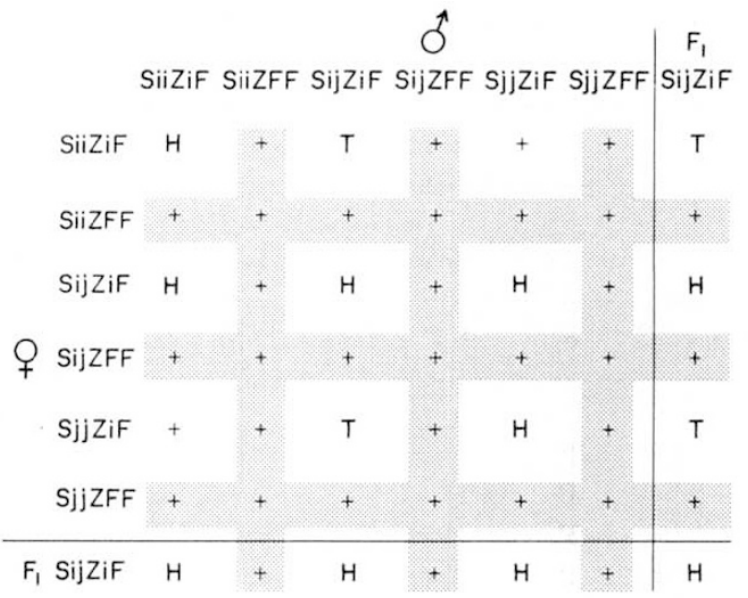

Fig. 2 Theoretical pattern of pollinations amongst $F_{2}$ plants. Self-compatibility mutation at $S$ or $Z$ locus (Model I) $\mathrm{H}=$ half compatible, $\mathrm{T}=$ three-quarters compatible, $+=$ fully compatible. Shaded area $=$ fully compatible male arrays (vertical) and female arrays (horizontal).

question of its relationship to the two-locus $S Z$ incompatibility system. Self-compatibility may have arisen by two alternative pathways, namely a mutation at either of the two incompatibility loci or by a mutation at a third locus. Differentiation between these two hypotheses requires consideration of the differing mating types which would appear in the $F_{2}$ and depends on two assumptions; homozygosity at the $S$ and $Z$ loci and proper functioning of these loci. If selfcompatibility is due to a mutation at $S$ or $Z$ (Model I) six different genotypes are expected in the $F_{2}$ whilst the alternative, namely a mutation outside of the $S Z$ system (Model II), will give rise to 18 . A pollination diallel of members of the $F_{2}$ generation will lead to differing patterns of inter-compatibility according to which model applies as shown in Figs 2 and 3. As can be seen from Fig. 2, on Model I, plants fully self-compatible are also fully cross-compatible whereas on Model II (Fig. 3 ), full cross-compatibility is only expressed throughout the male arrays. Reciprocal differences of the form partially/fully compatible are expected with Model II whenever the self-compatibility gene is homozygous in one parent and heterozygous in the second. By use of the $F_{1}$ as a pollen parent onto the members of the $F_{2}$, fully compatible reactions are expected in half of the cases for Model I, whereas none are expected for Model II.

The results of the intra- $\mathrm{F}_{2}$ pollination diallel are shown in Tables $1(\mathrm{a})$ and (b) from which it can be seen that, while all plants identified as fully self-compatible are cross-compatible as male parents, they are sometimes partially compatible as female parents. On the other hand $\mathrm{F}_{2}$ plants which are half self-compatible

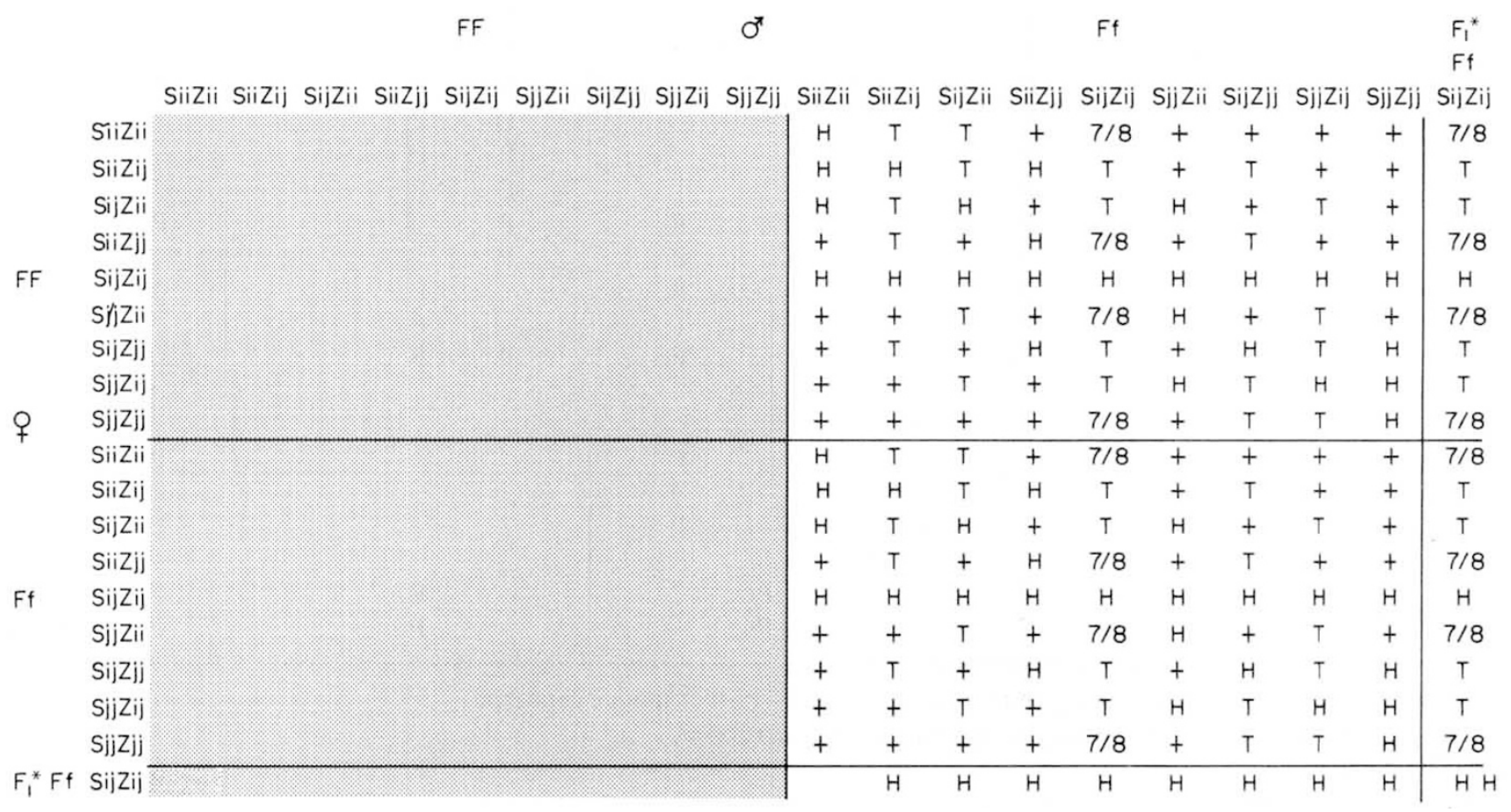

Fig. 3 Theoretical pattern of pollinations amongst $\mathrm{F}_{2}$ plants. Self-compatibility mutation at a locus additional to the $S$ and $Z$ loci (Model II) $\mathrm{H}=$ half compatible, $\mathrm{T}=$ three-quarters compatible, $7 / 8=$ seven-eighths compatible, $+=$ fully compatible, shaded area $=$ fully compatible male arrays, ${ }^{*}$ reaction of the $F_{1}$ when used as a pollinator or stigmatic parent. 
Table 1 (a) Partial diallel of pollinations involving half self-compatible $F_{2}$ and $F_{1}$ plants as males. (b) Partial diallel involving pollination of fully self-compatible $F_{2}$ plants as males

(a)

$\sigma^{\prime}$

\begin{tabular}{|c|c|c|c|c|c|c|c|c|c|c|c|c|c|c|c|c|c|c|}
\hline & & sility & 2 & 4 & 7 & 8 & 9 & 11 & 15 & 15 & 17 & 18 & 19 & $?$ & $?$ & $?$ & $F_{1}$ & $F_{1}$ \\
\hline & & $\mathrm{F}_{2}$ plt & $18 / 3$ & $24 / 1$ & $16 / 1$ & $15 / 1$ & $18 / 2$ & $17 / 1$ & $4 / 4$ & $18 / 5$ & $7 / 1$ & $8 / 5$ & $9 / 4$ & $15 / 2$ & $15 / 3$ & $2 / 5$ & 1 & 17 \\
\hline q & 1 & $17 / 3$ & & $P$ & & + & & & & & & & + & & & & & \\
\hline & 1 & $12 / 3$ & & $\mathbf{P}$ & + & + & + & $\mathbf{P}$ & & & + & $P$ & + & + & & & $P$ & \\
\hline & 1 & $17 / 5$ & & $P$ & & + & & & & $\mathbf{P}$ & & $P$ & + & & & & & \\
\hline & 2 & $18 / 3$ & $\mathrm{H}$ & & & + & & & & & & $P$ & + & + & & & & \\
\hline & 3 & $10 / 3$ & & $\mathbf{P}$ & + & $\mathbf{P}$ & + & + & & + & + & $P$ & $P$ & & & & $P$ & $\mathbf{P}$ \\
\hline & 3 & $12 / 14$ & & $P$ & & $\mathbf{P}$ & + & + & + & + & & & $\mathbf{P}$ & & & & & \\
\hline & 4 & $24 / 1$ & & $\mathbf{H}$ & + & $\mathbf{P}$ & + & + & & + & & $\mathrm{P}$ & $P$ & & & & $\mathbf{P}$ & $\mathbf{P}$ \\
\hline & 5 & $8 / 2$ & & $\mathbf{P}$ & + & $\mathbf{P}$ & + & $\mathbf{P}$ & & + & + & $P$ & $\mathbf{P}$ & & & & $P$ & $\mathbf{P}$ \\
\hline & 6 & $1 / 3$ & & $\mathbf{P}$ & & $P$ & & $\mathbf{P}$ & & $\mathbf{P}$ & & $P$ & $\mathbf{P}$ & & + & & & \\
\hline & 6 & $5 / 4$ & & $P$ & + & $\mathrm{P}$ & + & $\mathbf{P}$ & & $\mathbf{P}$ & + & $P$ & $\mathbf{P}$ & & + & $\mathrm{P}$ & $\mathbf{P}$ & $\mathbf{P}$ \\
\hline & 7 & $16 / 1$ & & $\mathbf{P}$ & $\mathrm{H}$ & + & + & $\mathbf{P}$ & & + & $P$ & + & + & & & & $P$ & $P$ \\
\hline & 8 & $15 / 1$ & & $\mathbf{P}$ & + & $\mathbf{H}$ & $\mathbf{P}$ & + & & & $P$ & $P$ & $\mathbf{P}$ & & & & $P$ & $P$ \\
\hline & 9 & $18 / 2$ & & $\mathbf{P}$ & $\mathbf{P}$ & + & $\mathrm{H}$ & + & & $\mathbf{P}$ & $\mathbf{P}$ & + & + & & & & $\mathbf{P}$ & $\mathbf{P}$ \\
\hline & 10 & $11 / 2$ & & $P$ & $\mathrm{P}$ & $\mathrm{P}$ & $P$ & $\mathbf{P}$ & & $\mathbf{P}$ & & & $P$ & & $\mathbf{P}$ & $\mathbf{P}$ & $P$ & \\
\hline & 10 & $7 / 5$ & & $\mathbf{P}$ & & $\mathrm{P}$ & $\mathbf{P}$ & $\mathbf{P}$ & $P$ & & + & $P$ & $\mathbf{P}$ & & & & $\mathbf{P}$ & $P$ \\
\hline & 11 & $17 / 1$ & & + & & + & $\mathbf{P}$ & $\mathrm{H}$ & $\mathrm{P}$ & & & + & + & & & & & \\
\hline & 11 & $10 / 1$ & $P$ & + & & & & & & & & + & + & + & & & & \\
\hline & 12 & $2 / 1$ & & + & & + & & + & & + & & + & + & & & & & \\
\hline & 13 & $24 / 4$ & + & $\mathbf{P}$ & & + & & & & & & $\mathbf{P}$ & $\mathbf{P}$ & + & & & & \\
\hline & 13 & $24 / 3$ & & $\mathbf{P}$ & & + & + & & & + & + & $P$ & $P$ & & & & $\mathbf{P}$ & p \\
\hline & 14 & $23 / 5$ & & $\mathbf{P}$ & & $\mathbf{P}$ & + & + & & $\begin{array}{l}P \\
H\end{array}$ & & $\begin{array}{l}\mathrm{P} \\
\mathrm{P}\end{array}$ & $\begin{array}{l}\mathbf{P} \\
\mathbf{P}\end{array}$ & $\mathbf{P}$ & $t$ & & P & $\mathrm{P}$ \\
\hline & $\begin{array}{l}15 \\
15\end{array}$ & $\begin{array}{l}18 / 5 \\
4 / 4\end{array}$ & & $\begin{array}{l}P \\
P\end{array}$ & & $\begin{array}{l}P \\
P\end{array}$ & + & + & $\mathrm{H}$ & $\mathrm{H}$ & & $P$ & $\mathbf{P}$ & & + & $\mathbf{P}$ & $P$ & \\
\hline & 16 & $12 / 1$ & & $P$ & & $\mathbf{P}$ & & + & & $P$ & & $\mathrm{P}$ & $P$ & & $P$ & $P$ & & \\
\hline & 17 & $7 / 1$ & + & $\mathbf{P}$ & $\mathrm{P}$ & $\mathbf{P}$ & $P$ & $\mathbf{P}$ & & & $\mathrm{H}$ & $P$ & $\mathrm{P}$ & $\mathbf{P}$ & & $\mathrm{P}$ & $\mathrm{P}$ & $P$ \\
\hline & 18 & $8 / 5$ & & $\mathbf{P}$ & & $\mathbf{P}$ & & & & & & $\mathrm{H}$ & $\mathbf{P}$ & & & & & \\
\hline & 19 & $9 / 4$ & & $P$ & & $\mathbf{P}$ & & & & & & $P$ & $\mathrm{H}$ & & & & & \\
\hline & $?$ & $23 / 4$ & & $\mathbf{P}$ & & $\mathbf{P}$ & $P$ & & & & & $\mathbf{P}$ & $P$ & & & & & \\
\hline & $?$ & $8 / 1$ & & $\mathrm{P}$ & & $\mathbf{P}$ & + & & + & $\mathbf{P}$ & & $P$ & + & & & $\mathbf{P}$ & & \\
\hline & $?$ & $5 / 5$ & & $P$ & & $P$ & & $\mathbf{P}$ & & $\mathbf{P}$ & & $P$ & & & $P$ & & & \\
\hline & $?$ & $1 / 4$ & + & $\mathrm{P}$ & & $P$ & & & & $\mathbf{P}$ & & & $P$ & $\mathbf{P}$ & & & & \\
\hline & $?$ & $15 / 2$ & $\mathbf{P}$ & $P$ & & $\mathbf{P}$ & & & & & & & $P$ & $\mathrm{H}$ & & & & \\
\hline & $?$ & $11 / 5$ & & $\mathbf{P}$ & & $\mathbf{P}$ & & & & $\mathbf{P}$ & & $P$ & $\mathbf{P}$ & & & & & \\
\hline & $?$ & $2 / 4$ & & & & & & & & & & & & & $\begin{array}{l}+ \\
+\end{array}$ & + & & \\
\hline & $?$ & $\begin{array}{l}6 / 2 \\
15 / 3\end{array}$ & & & & & & & & $\mathbf{P}$ & & & & & $\begin{array}{l}+ \\
\mathrm{H}\end{array}$ & $P$ & & \\
\hline & $?$ & $\begin{array}{l}15 / 3 \\
2 / 5\end{array}$ & & & & & & & & + & & & & & $\mathrm{P}$ & $\mathrm{H}$ & & \\
\hline & $?$ & $5 / 3$ & & & & & & & & $\mathbf{P}$ & & & & & + & $P$ & & \\
\hline & $?$ & $11 / 4$ & & & & & & & & & & & & & & & & \\
\hline$F_{1}$ & & 1 & $\mathbf{P}$ & $\mathbf{P}$ & $\mathrm{P}$ & $\mathbf{P}$ & & & $P$ & & & & $\mathbf{P}$ & & & $P$ & $\mathrm{H}$ & $\mathrm{H}$ \\
\hline$F_{1}$ & & 17 & & $\mathbf{P}$ & $\mathrm{P}$ & $\mathbf{P}$ & & & $\mathrm{P}$ & & & & $\mathrm{P}$ & & & $P$ & $\mathrm{H}$ & $\mathrm{H}$ \\
\hline
\end{tabular}

$?=$ Could be placed in more than one group or may represent a further unique genotype.

Note that male and female compatibility groupings are not interrelated.

$+=$ Fully compatible.

$\mathrm{P}=$ Partially compatible.

$\mathrm{H}=$ Half self-compatible. 
(b)

0

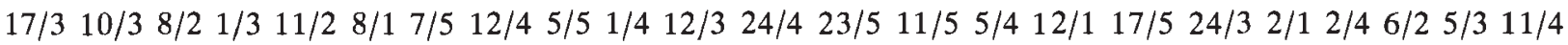

\begin{tabular}{|c|c|c|c|c|c|c|c|c|c|c|c|c|c|c|c|c|c|c|c|c|c|c|c|}
\hline ᄋ $17 / 3$ & + & + & + & + & & & & & & & & & & & & + & & & & & & & \\
\hline $10 / 3$ & + & + & + & + & + & + & + & & + & + & & & & & + & & + & + & & & & & \\
\hline $8 / 2$ & + & + & + & + & + & + & + & & & & & & & & & & + & + & & & & & \\
\hline $1 / 3$ & + & + & + & + & & + & & & + & & + & & & & & + & + & & + & & + & + & + \\
\hline $16 / 1$ & + & + & + & + & + & + & + & & & + & + & & + & & & & + & + & & + & & & \\
\hline $15 / 1$ & + & + & + & + & + & & + & & + & & & & + & & + & & + & + & & & & & \\
\hline $24 / 1$ & + & + & + & + & & + & + & & + & + & & + & & + & & + & + & & & & & & + \\
\hline $8 / 5$ & + & + & + & + & & & & & & & & & & & & & & & & & & & \\
\hline $9 / 4$ & + & + & + & + & + & + & + & + & + & & & & & & & & & & & & & & \\
\hline $18 / 2$ & + & + & + & + & + & + & + & + & + & & + & & + & & & & + & + & & & & & \\
\hline $23 / 4$ & + & + & + & + & & & & & & & & & & & + & & & & & & & & \\
\hline $4 / 4$ & + & + & + & + & + & + & + & + & + & & & & + & & & & & & & & & & \\
\hline $11 / 2$ & + & + & + & + & + & & & & & & + & & + & & & & & + & & & & + & \\
\hline $8 / 1$ & + & + & + & + & + & + & + & + & + & & & & + & & & & + & & & & & & + \\
\hline $7 / 5$ & + & + & + & + & + & + & + & + & + & & + & + & + & & + & & + & + & & + & & & \\
\hline $17 / 1$ & + & + & + & + & + & + & + & + & + & & + & + & + & & & & & & & & & & \\
\hline $12 / 4$ & + & + & + & + & + & + & + & + & + & + & & + & + & & & & & & & & & & \\
\hline $5 / 5$ & + & + & + & + & + & + & + & & + & + & & + & & & & + & + & & & & & & + \\
\hline $7 / 1$ & + & + & + & + & + & & + & & & + & + & + & + & & & + & & + & & & & & + \\
\hline $10 / 1$ & + & + & + & + & & & & & & + & & + & & & & & & & & & & & \\
\hline $1 / 4$ & + & + & + & + & & + & & & + & + & & + & + & & & & + & & & & & & \\
\hline $12 / 3$ & + & + & + & + & + & & & & & + & & & + & & & & & + & & & & & \\
\hline $15 / 2$ & + & + & + & + & & & & & & + & & & + & & & & & & & & & & \\
\hline $24 / 4$ & + & + & + & + & & & & & & + & & & + & & & & & & & & & & \\
\hline $10 / 3$ & + & + & + & + & & & & & & + & & & & & & & & & & & & & \\
\hline $23 / 5$ & + & + & + & + & + & + & & & & + & + & & + & & + & & + & + & & & & & \\
\hline $11 / 5$ & + & + & + & + & & & & & & & & & & + & & & & & $\begin{array}{l}+ \\
+\end{array}$ & + & + & + & + \\
\hline $18 / 5$ & + & + & + & + & & + & & & + & & & & & & + & + & $\begin{array}{l}+ \\
+\end{array}$ & $\begin{array}{l}+ \\
+\end{array}$ & + & . & + & + & + \\
\hline $5 / 4$ & + & + & + & + & + & + & + & & + & & + & & + & & + & + & + & $\begin{array}{l}+ \\
+\end{array}$ & + & + & + & + & + \\
\hline $12 / 1$ & + & + & + & + & & & & & & & & & & + & + & + & + & $\begin{array}{l}+ \\
+\end{array}$ & $\begin{array}{l}+ \\
+\end{array}$ & + & + & + & ${ }^{\top}$ \\
\hline $17 / 5$ & + & + & + & $\begin{array}{l}+ \\
+\end{array}$ & + & + & & & & & & & + & + & & & $\begin{array}{l}+ \\
+\end{array}$ & + & + & & & $\mathrm{T}$ & \\
\hline $\begin{array}{l}24 / 3 \\
2 / 1\end{array}$ & + & $\begin{array}{l}+ \\
+\end{array}$ & $\begin{array}{l}+ \\
+\end{array}$ & $\begin{array}{l}+ \\
+\end{array}$ & + & + & & & $\begin{array}{l}+ \\
+\end{array}$ & & + & & $T$ & + & & & + & $T$ & + & & & & \\
\hline $\begin{array}{l}2 / 1 \\
2 / 4\end{array}$ & $\begin{array}{l}+ \\
+\end{array}$ & & & & & & & & & & & & & & & + & + & & & & + & + & + \\
\hline $6 / 2$ & & & & & & & & & & & & & & & + & + & & & & & + & + & + \\
\hline $15 / 3$ & + & & & & & & & & & & & & & & + & + & & & & + & & + & + \\
\hline $2 / 5$ & + & & & & & & & & & & & & & & + & + & & & & + & + & + & + \\
\hline $5 / 3$ & + & & & & & & & & & & & & & & + & + & & & & + & + & + & + \\
\hline $11 / 4$ & + & & & & & & & & & & & & & & + & & & & & + & & & + \\
\hline$F_{1} 1$ & + & & & & & & + & & & & & + & & & & + & + & & & + & + & & \\
\hline$F_{1} 17$ & + & & & & & & + & & & & & + & & + & & & + & & & & + & & \\
\hline
\end{tabular}

$+=$ Fully compatible.

give rise to both partial and fully compatible reactions both as male and female parents. The number of mating groups to which the $F_{2}$ plants may be allocated is 19 , with a further 12 plants being unclassified. These latter plants may be allotted to more than one group or could represent unique genotypes. The occurrence of more than the 18 classes expected if the second hypothesis, Model II, applies may be accounted for by two possible explanations. First, errors in scoring the large numbers of pollinations cannot be ruled out although this is unlikely in view of the fact that one is differentiating between only partially and fully com- 
patible reactions (see Cornish, 1979). Associated with possible misclassification, the excess of partially compatible individuals in the $\mathrm{F}_{3}$ may reflect a viability disturbance in the pollen which, if manifest in the $F_{2}$ although not detected in the overall classification could lead to what in fact were fully compatible pollinations being wrongly scored as partially compatible. Secondly, failure of one of the assumptions, namely heterozygosity at either of the incompatibility loci in one of the original parents leading to a heterogeneous $F_{1}$ would also give rise to a greater number of classes than expected in the $F_{2}$. As indicated previously, however, no heterogeneity was detected in the $F_{1}$ diallel.

The results of using two of the $F_{1}$ plants as pollinators are also shown in Table 1. For both pollinators the reaction observed was of partial compatibility throughout. If the origin of self-compatibility is by mutation at either the $S$ or $Z$ locus (Model I) half of the pollinations are expected to be fully compatible. Whilst the observed result could have arisen by chance sampling, the probability of it occurring in the two sets of 10 and 13 individuals is less than 1 in 1000 when considered separately and less than 1 in $10^{6}$ when they are combined. We may safely conclude therefore that Model I does not apply.

The general pattern of results is indicative of a selfcompatibility gene $(S c)$ being operative in this material which is non-allelic to the $S$ and $Z$ loci. In rye (Secale cereale) Lundqvist (1968) proposed the existence of a similar additional locus. In a closely related species, Lolium temulentum, it has been shown that self-fertility is probably due to a mutation at the $Z$ locus (Thorogood \& Hayward, 1988). This gene has been successfully transferred to $L$. perenne and $L$. multiflorum and is fully functional in the changed genetic background. It would thus appear that in the Lolium genus self-fertility may arise by at least two alternative pathways. The occurrence of a locus additional to the $S$ and $Z$ loci must raise questions as to whether the twolocus system has arisen by gene duplication, as proposed by Lundqvist (1962b), or whether it represents a remnant of a multilocus mechanism. The possible occurrence of multilocus systems has been suggested for the grasses by Lundqvist et al. (1973) on the basis of their findings of three loci in Ranunculus acris and at least four in Beta vulgaris. In the grass species, Briza spicata, self-incompatibility is thought to be controlled by more than two loci (Murray, 1979). The expression of any relic locus could well be activated by the change in genetic balance brought about by the enforced inbreeding that has taken place. That such changes in the expression of incompatibility loci can occur when the genetic balance is disrupted is well established in a number of species and their hybrids (Darlington \& Mather, 1949; de Nettancourt, 1977).

\section{Acknowledgements}

We are indebted to Dr R. N. Jones of The Department of Agricultural Sciences, University College of Wales, Aberystwyth and Dr U. K. Posselt of The University of Stuttgart for providing the inbred parental lines, and to Mr N. J. McAdam at the Welsh Plant Breeding Station for producing the $F_{1}$ and $F_{2}$ families. We would also like to thank Dr M. J. Lawrence of the Department of Genetics, University of Birmingham for valuable discussion. D.T. acknowledges receipt of a 3-year postgraduate studentship from the A.F.R.C.

\section{References}

ALBINI, S. M. 1982. Variation in inbred lines of Lolium perenne. MSc Thesis, University of Wales.

ATwOOD, S. S. 1942. Genetics of psuedo-self-compatibility and its relation to cross incompatibility in Trifolium repens. $J$. Agric. Res., 64, 699-709.

BEAN, E. W. AND YOK-HWA, C. 1972. An analysis of the growth of inbred progeny of Lolium. J. Agric. Sci., 79, 147-153.

BEDDOWS, A. R., BREESE, E. L. AND LEWIS, E. J. 1962. The genetic assessment of heterozygous breeding material by means of a diallel cross. 1. Description of parents, self and cross fertility and early seedling vigour. Heredity, 17, 501-512.

CORNISH, M. A. 1979. The genetics of self-incompatibility in Lolium perenne. Ph.D thesis, University of Birmingham.

CORNISH, M. A., HAYWARD, M. D. AND LAWRENCE, M. J. 1979. Selfincompatibility in ryegrass. I. Genetic control in diploid Lolium perenne L. Heredity, 43, 95-106.

DARLINGTON, C. D. AND MATHER, K. 1949. Elements of Genetics, Allen and Unwin Ltd.

EAST, E. M. 1932. Studies on self sterility. IX. The behaviour of crosses between self-sterile and self-fertile plants. Genetics, 17, 175-202.

FEARON, C. H., HAYWARD, M. D. AND LAWRENCE, M. J. 1983. Selfincompatibility in ryegrasses. V. Genetic control, linkage and seed set in diploid Lolium multiflorum Lam. Heredity, 50, 35-45.

HAYMAN, D. C. 1956. The genetical control of incompatibility in Phalaris caerulescens Desf. Aust. J. Biol. Sci., 9 , 321-331.

JENKIN, T. J. 1931. Self-fertility in Lolium perenne L. Welsh Plant Breeding Station Bulletin, No. 12, 100-119.

JONES, R. N. AND JENABZADEH, P. 1981. Variation in self-fertility, flowering time and inflorescence production in inbred Lolium perenne. J. Agric. Sci., 96, 521-537.

LALOUETTE, J. A. 1967. Growth of grass pollen when exhibited by the callose fluorochrome reaction. Grana Polynologica, 7, 601-603.

LUNDQVIST, A. 1956. Self-incompatibility in rye. I. Genetic control in the diploid. Hereditas, 42, 293-348. 
LUNDQVIST, A. 1960. The origin of self-compatibility in rye. Hereditas, 46, 1-19.

LUNDQVIST, A. 1961. A rapid method for the analysis of incompatibility in grasses. Hereditas, 47, 705-707.

LUNDQVIST, A. 1962a. Self-incompatibility in diploid Hordeum bulbosum L. Hereditas, 48, 138-152.

LUNDQVIST, A. $1962 \mathrm{~b}$. The nature of the two loci incompatibility system in grasses. I. The hypothesis of a duplicative origin. Hereditas, 48, 153-168.

LUNDQVIST, A. 1965. Self-incompatibility in Dactylis ascersoniana Groebn. Hereditas, 54, 70-87.

LUNDQVIST, A. 1968. The mode of origin of self-fertility in grasses. Hereditas, 59, 413-426.

LUNDQVIST, A., OSTERBYE, U., LARSEN, K. AND LINDELAURSEN, I. 1973. Complex self-incompatibility systems in Ranunculus acris L. and Beta vulgaris L. Hereditas, 74, 161-168.

MARTIN, F. W. 1968. The behavior of Lycopersicon incompatibility alleles in an alien genetic milieu. Genetics, 60, 101-109.

MatHeR, K. 1943. Specific differences in Petunia. I. Incompatibility. J. Genet., 45, 215-235.

MURRAY, B. G. 1974. Breeding systems and floral biology in the genus Briza. Heredity, 33, 285-292.
MURRAY, B. G. 1979. The genetics of self-incompatibility in Briza spicata. Incompat. Newsletter, 11, 42-45.

NETTANCOURT, D. DE 1977. Incompatibility in Angiosperms. Monographs on Theoretical and Applied Genetics, 3. Springer-Verlag, Berlin.

THOROGOOD, D. 1991. Self-fertility in Lolium. Ph.D thesis, University of Wales.

THOROGOOD, D. AND HAYWARD, M. D. 1988. The genetic control of self-fertility in Lolium temulentum. Heredity, 61, 288.

TOWNSEND, C. E. 1965. Self-compatibility studies with diploid alsike clover, Trifolium hybridum. I. Frequency of selfcompatible plants in diverse populations and inheritance of a self compatibility factor $\left(S_{\mathrm{f}}\right)$. Crop Sci., 5, 358-360.

TOWNSEND, C. E. 1966. Self-compatibility studies with diploid alsike clover, Trifolium hybridum. II. Inheritance of a self compatibility factor with gametophytic and sporophytic characteristics. Crop Sci., 6, 415-419.

UTZ, H. F. AND OETTLER, G. 1978. Performance of inbred lines and their top-crosses in perennial ryegrass (Lolium perenne L.) Z. Pflanzen., 980, 223-229.

WEXELSEN, н. 1952. The use of inbreeding in forage crops. Proc. 6th Int. Grassld. Con., vol. I, pp. 299-305. 